\title{
Issues at the Rural-Urban Fringe: Will Florida Be Prepared for 2030?1
}

Rodney L. Clouser²

\section{Introduction}

Florida's population growth over the last 100 years is well documented. In 1900, the state's population was just under 529,000 people and, by 2000, had increased to just less than 16 million. These large population increases over time may have caused some Floridians to become complacent about the rate of population change, and be indifferent to additional growth over the next 25 years. However, U.S. Census Bureau population projections estimate Florida's 2030 population will be almost 29 million residents. This is equivalent to importing the 2000 population of Ohio to Florida over a 30-year period. Another perspective, if those populations rates are achieved, is that on average over 1,100 people will be born in or move to Florida every day for 30 consecutive years!

Existing and new state residents will place many demands on the state's fiscal, human, and natural resources. Population increases will impact water and land allocations and decisions; state, county, and community infrastructure needs for local goods and services such as roads, schools, waste disposal, medical facilities, jails and recreation; and the means to fund basic services provided by different levels of government. To many state residents, the year 2030 seems a long way off into the future. Granted, 25 years may seem like a long planning horizon, but it is not that lengthy when you think in terms of planning, financing, and constructing major infrastructure. Additionally, if we do not start the process of thinking about and establishing policy directions for future issues that will be influenced by the choices we make currently, then we could create additional problems or delay implementation of policies to help solve those issues. Specific solutions to some of the future policy issues that must be addressed are not discussed in this fact sheet, but some of the policy issues of importance within the state are identified.

\section{National and Regional Perspective: The South and Florida Lead in Population Growth}

Nationally, the U.S population is expected to grow by approximately 82.2 million people between 2000 and 2030. Slightly more than 50 percent of this growth will occur in 13 southern states (Alabama, Arkansas, Florida, Georgia, Kentucky, Louisiana, Mississippi, North Carolina, Okalahoma, South Carolina, Tennessee, Texas, and Virginia). These

1. This is EDIS document FE661, a publication of the Food and Resource Economics Department, Florida Cooperative Extension Service, Institute of Food and Agricultural Sciences, University of Florida, Gainesville, FL. Published August 2006. Please visit the EDIS website at http://edis.ifas.ufl.edu.

2. Rodney L. Clouser, Professor, Food and Resource Economics Department, Florida Cooperative Extension Service, Institute of Food and Agricultural Sciences, University of Florida, Gainesville, FL.

The Institute of Food and Agricultural Sciences (IFAS) is an Equal Opportunity Institution authorized to provide research, educational information and other services only to individuals and institutions that function with non-discrimination with respect to race, creed, color, religion, age, disability, sex, sexual orientation, marital status, national origin, political opinions or affiliations. U.S. Department of Agriculture, Cooperative Extension Service, University of Florida, IFAS, Florida A. \& M. University Cooperative Extension Program, and Boards of County Commissioners Cooperating. Larry Arrington, Dean 
states are identified in Figure 1 with red boxes.

However, growth in these southern states is heavily concentrated. Seven states in Figure 1 with white boxes (Florida, Georgia, North Carolina, South Carolina, Tennessee, Texas, and Virginia) account for over 47 percent (38.7 million) of the population growth in the United States by 2030. Three southern states (Florida, North Carolina, and Texas) identified by blue boxes in Figure 1 will account for approximately 36 percent of all U.S. population growth. Florida alone will account for 15.5 percent of the U.S. population growth between 2000 and 2030.
Florida's economy. However, 2004 tourist visits to the state increased three percent over 2003 (from 74.6 to 76.8 million), and although not released yet, official tourist estimates are expected to exceed 80 million in 2005. Additionally, consider that Flagler County has been the fastest-growing county in the country from 2002-2004 and the fastest-growing county in the country between 2000 and 2004. Florida also has the distinction of having the most counties (14) of the nation's 100 fastest-growing counties of any state in the United States.

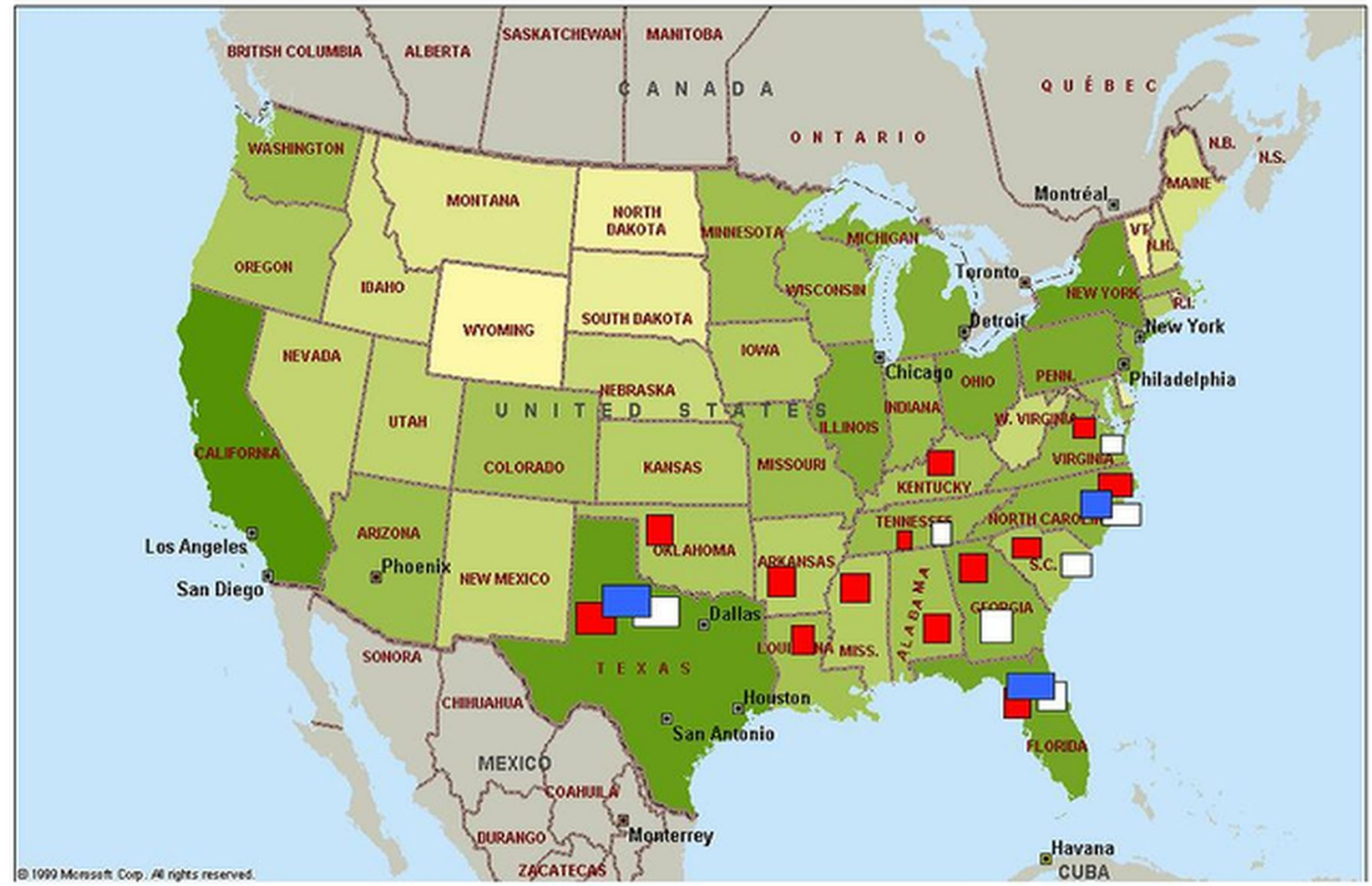

Figure 1. Projected population growth in southern states, 2030. Credits: Source: Map Point.

Of the seven largest-growth states in the south, all, except for Tennessee, have coastal exposure. This coastal exposure comes with the risk of tropical storms and hurricanes. For example, Florida had seven hurricanes (Charley, Dennis, Frances, Ivan, Jeanne, Katrina, and Wilma) impacting the state in 2004 and 2005. The four 2004 storms (Charley, Frances, Ivan, and Jeanne) resulted in estimated damage of about $\$ 45$ billion dollars. Yet there is no data indicating potential long-term impacts on the state's population growth. Some people feared these storms would have a large impact on the state's tourism industry, which is an important sector of
The fastest-growing states nationally, in both percentage growth and absolute growth, are identified in Table 1. While the overall U.S. population will increase 29 percent between 2000 and 2030, the growth rates in the five fastest-growing states will exceed 56 percent. In percentage terms, Florida will rank as the third fastest in population growth (79.5 percent), trailing only Arizona and Nevada. However, Florida is much more populous than either of these states. In terms of total growth in population, Florida will have a larger population growth between 2000 and 2030 (12.7 million people) than any state in the country. California and Texas will closely follow 
Florida in terms of total population growth at 12.5 million each. Four of the states with the largest total-population growth have coastal areas. Four of the five largest-growth states in percentage terms (Arizona, Florida, Nevada, and Texas) are in relatively warm climates, and all over time have had concerns with water availability and use. A common element among the fastest-growth states seems to be the relationship between population growth and land and water demands/competition, both fresh and saltwater.

A summary of the population growth outlook for Florida between 2000 and 2030 is:

- Florida will be the fastest-growing state in terms of total population, increasing by roughly 12.7 million people.

- Florida's population will increase from just less than 16 million to almost 29 million.

- Two-thirds of the population growth (8 million) could be concentrated in about one-third (20-22) of the state's counties.

- Demand and competition for land and water resources will be soaring.

- A significant amount of Florida's growth will be the result of migration from other states.

- Florida's population growth could create several significant issues, many policy-related, that need to be addressed immediately to avoid future problems.

\section{Significant Future Growth-related Issues in Florida: Plan Now}

There may be an indefinable list of significant issues confronting state, county, and local governments and Florida residents over the next 25 years. The topics that follow should not be considered as all-inclusive, nor as the most important Florida must address. Rather, they should be viewed as a snapshot of the breadth and variety of issues that accompany rapid and large growth.

\section{Issue: Land Values, and Sustainable Agriculture and Natural Resources}

Florida's land area consists of approximately 34.5 million acres (53,906 square miles), including over 660 miles of beaches and 1,200 miles of coastal area. According to national information, approximately 70 percent (in excess of 24 million acres) of Florida's land area is in forest, pastureland, rangeland, and crops. Agriculture in Florida is a significant land owner, land user, and natural resource caretaker. It is also an important economic contributor to the state's economy. According to survey information collected on Florida land values, agricultural land values in the state are increasing rapidly. The survey indicated in 2005 that land used in production (crops, pasture, woods) was increasing in value between 50 and 85 percent per acre and that more than 80 percent of respondents expected land prices to increase over the next 12 months. Agricultural land was increasingly being converted to housing or other development purposes, with some sections in the state selling in excess of $\$ 100,000$ per acre.

It is next to impossible to sustain this land in agriculture over the long term. Production risk, input costs, and international and national competition do not result in profit margins sufficient to encourage producers to keep the land in production, nor allow for entry by new agricultural producers. New residents in the state may contribute to sprawl because it has been cheaper to "grow out rather than grow up." As more land is required for roads, schools, retail outlets, trade centers, hospitals, etc., the agricultural land base and the natural resource base (streams, ponds, lakes, woodlands, wildlife habitat, etc.) is diminishing.

Growth pressure in the state on agricultural lands will be enormous. Will we encourage sustainability of the industry at its current or a larger size, or will the industry and its associated benefits decline? How do you encourage compact growth that is affordable, maintains the value of land assets to producers, and supports an important segment of the state economy? 


\section{Issue: Affordable Housing}

Population growth typically results in higher housing values. This may occur for several reasons. For example, home building tends to lag behind population growth; building inputs tend to increase because demand outpaces construction supplies; labor costs tend to increase with population growth; speculation on future housing values tend to increase land prices; existing home values increase due to demand for immediate housing; and regulatory costs and the necessary infrastructure (roads, schools, etc.) to support new growth tend to increase rapidly.

Will Florida be like California and Nevada, where construction costs $\$ 400$ to $\$ 1,000$ per square foot in metropolitan areas? If so, where will the state's labor supply for retail, agriculture, and services live? The income earned by these workers will not support rapid growth in housing costs. In 2003, Florida's median family income in households with two wage earners was estimated at $\$ 49,500$, and the median Florida home value was estimated to be about $\$ 130,000$. The bottom line is that two-wage-earner households could have difficulties in purchasing a median-valued home, and the problem is most likely getting worse yearly.

If every new resident in the state projected for 2030 required just a little over 5,000 square feet for homes, lots, sidewalks, roads, schools, hospitals, stores, parks and recreation, etc., it would require another 1.6 million acres of urban, suburban, and related infrastructure space to accommodate these needs if the building demand is "out rather than up." How can you increase density and provide needed services for new residents at reasonable costs? How do you build housing that is affordable to the labor pool required in the state and keep them within reasonable distances of where they will be employed? How can you structure the housing market where young families with limited equity can afford home ownership? What happens to the local economy when increases in housing prices far outpace increases in wages? How do you keep the income and costs in balance?

\section{Issue: Age Distribution}

The 12.7 million new Florida residents expected in 2030 will show significant relative growth in people over the age of 65 . In 2000, people over 65 comprised about 17.6 percent ( 2.8 million) of the state's population, and it is estimated that they will account for 27.1 percent (7.8 million) in 2030, an increase of about 5 million. In 2000, those under the age of 18 in Florida numbered 3.6 million, and are estimated to number 5.8 million in 2030, an increase of 2.3 million.

People over 65 and those younger than 18 will account for about 57 percent of the state's total growth between 2000 and 2030. These bi-modal growths in age distribution ranges may be problematic because the types of services needed by the two groups are significantly different. The number of youth under the age of 18 indicates the need for more educational services. Assuming that the average school class size is 21 students, nearly 100,000 additional school teachers will be required in the state over the next 25 years. People over 65 will place greater demands on health and healthcare systems. Fiscal resources required for federal and state healthcare aid could increase dramatically. In addition, younger populations often demand more "active" recreational activities than do older populations. Where growth occurs and how the state handles the demand for services from these two categories of people are critical issues. What if the growth in school-age children is not in areas where existing school facilities with excess capacity exist? What if medical and assisted living facility capacities are below the needs in certain areas?

\section{Issue: Law Enforcement and Public Safety}

While increased criminal activity often accompanies population growth, not all criminal activity is of a violent nature and may include white-collar crime, parole violation, driver's license suspensions, failure to pay child support, etc. Using state prison population counts $(84,901)$ in June 2005 and average county jail population counts $(57,538)$ for 2005 indicates that approximately one out of every 120 people in Florida was incarcerated in 2005. Additionally, another 148,000 people in Florida had been released from incarceration but were under 
paroled supervision. This means that one in every 60 residents in Florida was incarcerated or under paroled supervision. Recent trends indicate these population counts have been increasing about four percent per year. If this rate continues for a 25 -year period, the number of people incarcerated or paroled more than doubles. Incarceration is not an inexpensive activity. Total expenditure for state correctional facilities only, including operation, administration, and capital outlay, was almost \$2 billion in fiscal year 2004-05, or over $\$ 18,000$ per incarceration, per year. Long term this cost could be expected to increase if the prison population reflects the state population age distribution. An increase in sentencing time could result in longer incarcerations, and an aging prison population may increase medical and healthcare costs. The bottom line is that Floridians are spending billions of dollars for jails, correctional facilities, and paroled supervision, and these expenditures are only going to increase unless alternatives are found.

To maintain the current ratios of police, fire, and ambulance services per 1,000 state residents in 2030 will require the number of people currently serving in these roles to increase by about 80 percent. How will we encourage people to enter these careers, provide the necessary job training, and retain them in these professions? What alternatives are available to maintain the state's public safety infrastructure at reasonable costs?

\section{Issue: Poltical Districts and Representation}

With increased state growth in population comes associated growth in political representation. Florida will gain significantly in terms of federal congressional representatives because of its rapid population growth. Some speculate that Florida may gain as many as three new federal representatives as soon as the 2010 population census is completed. If projected population trends hold true, Florida is likely to gain as many as nine new federal representatives by the year 2030 . Current 2030 population projections indicate three southern states, Florida, North Carolina, and Texas, will elect about 20 percent of the U.S. House of Representatives. Add California to the three southern states and over 33 percent of the House of Representatives will be elected from just four states. Significant electoral power will be very concentrated.
Maybe a more important question that needs to be addressed is: "How will the districts and the voters these federal representatives serve be established?" Currently, these districts are established by the Florida legislature. However, as recently noted in a USA Today editorial, "State legislators draw voting districts to guarantee their own survival and boost the election hopes of others in their party." In California's 2004 congressional elections, 50 incumbents ran and all were re-elected. None of the state's federal or state representatives legislative seats changed political parties. It can be argued that the majority of races were not competitive: in all 435 U.S. House races, only 23 seats (about 5 percent) were decided by less than 10 percentage points.

Florida elections exhibited a similar pattern in 2004. In 23 of the 25 U.S. House districts within the state, incumbents were re-elected. In the other two districts, new representatives were elected because there were no incumbents in the race. In none of the 25 districts did the political party change as a result of the election, and none of the races were decided by less than 10 percentage points. Is this a desired outcome? Is there another method to redraw political districts that will result in more competitive election races and better representation for Florida residents?

The scope of this issue goes beyond national elections and is equally important at the state and local level. If you are a county or city commissioner or a school board member, the number of constituents you represent will increase substantially in the next 25 years. How do you communicate with these constituents? How do you keep them updated on policy related issues? How do you know what their priorities on issues are? Florida's population growth will result in many locally-elected official constituent bases increasing by 80 percent or more.

\section{Issue: Water Resources}

Water quality, quantity, availability, and allocation has been a "hot" political policy issue in Florida for several decades. The state's rapid population growth will only make these issues more critical over the next 25 years. Although there are many interesting aspects to water issues in the state, one of the issues that has created much concern is the 
potential transferring of water from less densely populated north Florida to more heavily populated south Florida. Other states are also faced with this problem. For example, in 1986, Congress passed legislation requiring approval by all eight governors of the Great Lakes Basin before the transfer of any water out of the basin. Upon enactment by the individual state legislatures and consent of the U.S. Congress, the Great Lakes-St. Lawrence River Basin Water Resources Compact will be established. The compact is designed to "permit diversions to nearby communities but preclude exports to faraway regions." While the compact does not explicitly ban long-distance diversions, its provisions set stringent rules designed to discourage them. The eight states do not want to transfer water, bottled or otherwise, in significant quantities outside the basin. Some of that concern is related to growth in the southeast and fast-growth arid states in the west.

Alabama, Florida, and Georgia had a water compact negotiated in 1997 that is now in dispute and speculated to end up in litigation. The concern was that Atlanta would remove water for its rapidly growing population that should be flowing south to Alabama and Florida rivers. Population growth between now and 2030 will only increase the issues of water allocations. Speculation is these "water conflicts" will become worse because many of the fastest-growing states and communities are already in areas where water supplies are short. What policies will be effective in the allocation and conservation of water? If there is a shortage of water, how will it be allocated among competing uses? Do we invest in technology now, which may be very expensive, to alleviate longer-term water quantity issues?

\section{Issue: Infrastructure and Financing}

New residents will require new or improved services. This includes everything from sidewalks to roads. The infrastructure costs for the estimated 12.7 million new Florida residents may prove to be problematic. It is impossible in a short article to go into detail about all the needs, so transportation issues will be used as a practical example.

Anyone traveling on Florida's major roads recognizes at certain times during the year (holidays) and at certain times during the day (morning and evening rush hours) that commuting times increase significantly because of the quantity of people traveling. This has the potential to worsen as more people move to the state. The transportation issue is somewhat complex due to the different layers of financing and jurisdiction related to roads, as federal, state, county, and municipal governments are all involved. To simplify the issue, the example will be framed around state and county issues. The state and counties allocate dollars to the transportation system through a variety of taxes, including state and local gas taxes and impact fees for new construction.

The problem arises partially because the enacted state and local taxes are not keeping pace with the cost of construction. Embedded within this issue is the concern that road construction tends to encourage even more growth. While there are alternatives to individual commuting, the cost may be higher than for road construction, and the "pricing" of individual commuting has not encouraged the majority of people to change to alternative transportation methods. However, with rapidly escalating gas prices, this could change over time. This has created a transportation system in the state that focuses on lane, mile, and widening expansion. The dollar gap between the needs of the state and the availability of funds is large. A recent report on the Florida intrastate highway system places the dollar gap for this system near $\$ 30$ billion. Counties are reporting a cost per lane mile of several million dollars, with the cost of eminent domain for rights-of-way, attorney fees, and litigation continuing to skyrocket.

There are many questions that must be addressed in the future. Will the state remain focused on lane, mile, and widening expansion as the core of the transportation system? Can commuters be influenced to consider alternative transportation systems rather than cars? How can the state finance the transportation system? How does the state close the $\$ 30$ billion dollar gap that already exists and will continue to widen as costs increase faster than revenues? How can this be accomplished when decisions are made in a political context and many decision makers want to be re-elected? 


\section{Summary}

It is very difficult to predict the future. No one can say with certainty that Florida's population in 2030 will definitively be almost 29 million residents. In the next 25 years, many different things could occur that could alter these projections. National events, such as wars, recessions, and interest rates, and climatic conditions, such as hurricanes, could decrease these projections. Actions taken by state, county, and municipal governments could also affect population growth. However, it needs to be recognized that the long-term projections have been relatively accurate and, if anything, somewhat pessimistic.

Rural areas within counties have much at stake with respect to population growth because that is where available open land is plentiful. Small rural counties have limited staffs to deal with growth-related issues, and most rural tax rates do not raise as much revenue as urban tax rates. The cost of growth-related issues in small rural counties is often quite challenging.

The issues raised in this article are not all-encompassing and may change over time. For example, recent hurricanes have affected homeowner and property insurances, and could directly affect the state's future population growth. Florida will face many challenges over the next 25 years that are directly related to population growth; some of those issues are presented in this article. Now is the time to start addressing those issues before they become more troublesome and solutions become more limited.

\section{References}

Arrandale, Tom. 2004. Guide to Water Rights beyond the Basin. Governing Magazine Online. http://www.governing.com/archive/2004/dec/water.txt . Website visited March 2006.

Barnett, Cynthia. 2006. Final Frontier. Florida Trend Magazine (July).

Clouser, Rodney L., and Hank Cothran. 2005. Issues at the Rural-Urban Fringe: Florida's Population Growth, 2004-2010. Electronic Data Information Source (EDIS) FE567. Food and
Resource Economics Department, University of Florida, Gainesville, FL. http://edis.ifas.ufl.edu/FE567.

Clouser, Rodney L. 2005. Issues at the Rural-Urban Fringe: The Land Use Debate-Situational Background. Electronic Data Information Source (EDIS) FE551. Food and Resource Economics Department, University of Florida, Gainesville, FL. http://edis.ifas.ufl.edu/FE551.

CSPAN Online. 2005. 2004 General Election Results. http://network.ap.org/dynamic/files/elections/2004/ general/national/ govsenhouse.html?SITE=CSPANELN\&SECTION=P OLITICS. Website visited January 2006.

Denslow, David, and Carol Weissert. 2005. Tough Choices Shaping Florida's Future. Leroy Collins Institute, Tallahassee, FL (October).

Florida Department of Corrections Online. Budget Summary FY 2004-05. http://www.dc.state.fl.us/pub/annual/0405/ budget.html. Website visited April 2006.

Jarrell, Jerry D, Max Mayfield, Edward N. Rappaport, and Christopher W. Landsea. 2005. The Deadliest, Costliest, and Most Intense U.S. Hurricanes from 1900 to 2000 (and Other Frequently Requested Hurricane Facts). NOAA/NWS/Tropical Prediction Center, Miami, FL (August).

Reynolds, John E. 2006. Strong Nonagricultural Demand Keeps Agricultural Land Values Increasing. Electronic Data Information Source (EDIS) FE625. Food and Resource Economics Department, University of Florida, Gainesville, FL. http://edis.ifas.ufl.edu/FE625.

USA Today. 2006. A Way to Put Competition Back into Elections. USA Today Editorial, June 29.

United States Census Bureau Online. Table 1. Urban and Rural Population: 1900 to 1990. http://www.census.gov/population/censusdata/ urpop0090.txt. Website visited April 2005. 
United States Census Bureau. 2005. Table 1.

Interim Projections: Ranking of Census 2000 and

Projected 2030 State Population and Change: 2000 to

2030. U.S. Census Bureau, Population Division, Interim State Population Projections, 2005. United

States Census Bureau, United States Department of

Commerce, Washington, D.C.

USDA/ERS Online. Profiles of America:

Demographic Data and Graphic Builder-Florida.

Economic Research Service, United States

Department of Agriculture, Washington, D.C.

http://maps.ers.usda.gov/Profiles/

index.aspx\#graphic_area. Website visited April 2005. 
Table 1. Top growth states, 2000-2030.

\begin{tabular}{|cr|cr|}
\hline \hline State & Percent Growth & State & Growth in Millions \\
\hline United States & 29.2 & United States & 82.2 \\
Nevada & 114.3 & Florida & 12.7 \\
Arizona & 108.8 & California & 12.5 \\
Florida & 79.5 & Texas & 12.5 \\
Texas & 59.8 & Arizona & 5.6 \\
Utah & 56.1 & North Carolina & 4.2 \\
\hline \hline
\end{tabular}

